\title{
Xylochloris irregularis gen. et sp. nov. (Trebouxiophyceae, Chlorophyta), a novel subaerial coccoid green alga
}

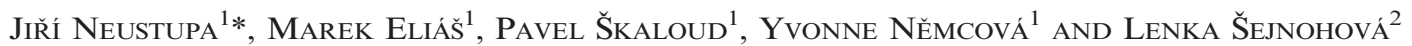 \\ ${ }^{1}$ Department of Botany, Faculty of Science, Charles University of Prague, Benátská 2, Praha 2, 128 01, Czech Republic \\ ${ }^{2}$ Institute of Botany, Czech Academy of Sciences, Květná 8, Brno, 603 65, Czech Republic
}

\begin{abstract}
Neustupa J., Eliáš M., ŠKaloud P., NĚmcová Y. And Šejnohová L. 2011. Xylochloris irregularis gen. et sp. nov. (Trebouxiophyceae, Chlorophyta), a novel subaerial coccoid green alga. Phycologia 50: 57-66. DOI: 10.2216/08-64.1

The phylogenetic diversity of subaerial coccoid green algae remains still poorly explored. We characterised in detail two unicellular green algae found on tropical trees in Singapore. Light microscopy revealed morphological identity of these two strains. Depending on the age of cultures, the cells were spherical to cylindrical, and ranged in size from 13.5 to $20.5 \mu \mathrm{m}$. Each cell contained a pyrenoid-bearing parietal chloroplast that was typically somewhat detached from the plasma membrane on its parietal side. The cells reproduced by 4-16 globular autospores. The 18S rRNA gene sequences of the two strains differed by only a single nucleotide, indicating probable conspecificity. Because the strains were morphologically most comparable to species of the genus Parietochloris, we determined the 18S rRNA gene sequences from authentic strains of three Parietochloris species ( $P$. alveolaris, P. cohaerens and P. ovoidea) for comparison. Molecular phylogenetic analyses placed all five examined strains into the class Trebouxiophyceae. The two novel tropical strains were found to be an independent lineage without an obvious sister group. The type species of the genus Parietochloris, $P$. alveolaris formed a monophyletic lineage with Parietochloris pseudalveolaris. Finally, $P$. cohaerens and P. ovoidea fell into another independent clade that also contained Lobosphaera tirolensis, L. incisa and Myrmecia bisecta, indicating that the genus Parietochloris as previously defined is polyphyletic. Based on our morphological and molecular phylogenetic data, we describe the two novel tropical strains as representatives of a new trebouxiophycean genus and species, Xylochloris irregularis gen. et sp. nov.
\end{abstract}

KeY Words: Chlorophyta, Subaerial algae, Taxonomy, Trebouxiophyceae, Xylochloris

\section{INTRODUCTION}

Coccoid green algae are possibly the most abundant and most diversified group of photoautotrophic microorganisms in terrestrial habitats. The majority of them belong to the green algal classes Trebouxiophyceae and Chlorophyceae, but terrestrial species of the Ulvophyceae and of several streptophyte lineages are also known (Ettl \& Gärtner 1995; Lewis \& McCourt 2004; Rindi et al. 2006; Škaloud 2006). That most terrestrial green algae are poor in easily detectable distinctive morphological features may be a major reason why our knowledge of their diversity still remains far from adequate, with numerous new species and lineages described only recently (Lewis \& Flechtner 2004; Rindi et al. 2006; Tschermak-Woess et al. 2006; Neustupa et al. 2007; Zhang et al. 2008; Eliáś \& Neustupa 2009; Neustupa et al. 2009; Eliáš et al. 2010). Especially in tropical regions with an obvious scarcity of data on subaerial microalgal diversity, many new taxa continue to be described (e.g. Rindi et al. 2006; Neustupa et al. 2007; Zhang et al. 2008; Neustupa et al. 2009; Eliáš et al. 2010), which may actually represent simply first members of potentially highly diversified and widespread lineages. Given these circumstances, systematic morphological, molecular phylogenetic and taxonomic characterization of these organisms is a critical step towards our understanding of subaerial microalgal diversity in the tropics.

\footnotetext{
*Corresponding author (neustupa@natur.cuni.cz).
}

In this study, we characterise two green algal strains collected from Southeast Asian tropical trees. We investigated the morphology of the strains and conducted molecular phylogenetic analyses based on the 18S rRNA gene. Because our new isolates morphologically resembled some representatives of the genus Parietochloris Watanabe $\&$ Floyd, we sequenced and analysed 18S rRNA genes from three Parietochloris strains available in public culture collections, namely, Parietochloris alveolaris (Bold) Watanabe \& Floyd (UTEX 836), Parietochloris cohaerens (Groover \& Bold) Watanabe \& Floyd (UTEX 1707) and Parietochloris ovoidea Mikhailyuk \& Demchenko (ACKU 177-03). On the basis of our results, we conclude that Parietochloris-like algae belong to several unrelated phylogenetic lineages within the green algal class Trebouxiophyceae, and to accommodate our tropical isolates we describe a new genus and species: Xylochloris irregularis gen. et sp. nov.

\section{MATERIAL AND METHODS}

\section{Collections and morphological investigations}

The two new algal strains were obtained from samples of epixylic subaerial algal biofilms. The strain CAUP H 7801 was isolated from an algal growth on decaying bare wood in a secondary forest in the Central Catchment Nature Reserve, Singapore [geographical coordinates $1^{\circ} 21^{\prime} 27^{\prime \prime} \mathrm{N}$ and $103^{\circ} 48^{\prime} 32^{\prime \prime} \mathrm{E}$; altitude $50 \mathrm{~m}$ above sea level (a.s.1.)]. The 
strain CAUP H 7802 was isolated from a microalgal growth on the bark of an unidentified dipterocarp tree in the Bukit Timah Nature Reserve, Singapore (geographical coordinates $1^{\circ} 21^{\prime} 11^{\prime \prime} \mathrm{N}$ and $103^{\circ} 46^{\prime} 42^{\prime \prime} \mathrm{E}$; altitude $100-120 \mathrm{~m}$ a.s.1.). Both samples were collected in the undergrowth of a closed-canopy forest, in a shaded habitat with limited direct illumination. The strains CAUP H 7801 and CAUP H 7802 have been deposited in the Culture Collection of Algae of Charles University in Prague (CAUP; http:// botany.natur.cuni.cz/algo/caup.html).

Three additional strains representing the genus Parietochloris were investigated in this study as well; they were obtained from the Culture Collection of Algae at the University of Texas (UTEX; http://www.sbs.utexas.edu/ utex) and the Culture Collection of Algae at Kyiv University, Ukraine (ACKU; Kostikov et al. 2009) Strain UTEX 836, isolated from a calcareous pool in Nashville, Tennessee (Bold 1958), is the authentic strain of Neochloris alveolaris Bold and has been later recombined as Parietochloris alveolaris (Watanabe \& Floyd 1989). Strain UTEX 1707, isolated in 1965 by L. Milliger from a soil sample taken in Bastrop State Park, Texas, is the authentic strain of Neochloris cohaerens Groover \& Bold and has been recombined by Watanabe \& Floyd (1989) as Parietochloris cohaerens. Strain ACKU 177-03 was isolated from epilithic subaerial biofilm on granite outcrops in Ukraine (Mikhailyuk et al. 2003) and is the authentic strain of Parietochloris ovoidea Mikhailyuk \& Demchenko. All the strains were cultivated on BBM agar medium (Bischoff \& Bold 1963) at $23^{\circ} \mathrm{C}$ with illumination of $40 \mu \mathrm{mol} \mathrm{m} \mathrm{m}^{-2} \mathrm{~s}^{-1}$ provided by 18-W cool fluorescent tubes (Philips TLD 18W/33). Microphotographs were taken with an Olympus BX51 light microscope and Olympus Z5060 camera using differential interference contrast. Induction of zoospore production was attempted by transferring the cultures from $\mathrm{BBM}$ to either distilled water or $1 \%$ glucose solution followed by keeping the cultures in darkness and/or at a temperature of $12^{\circ} \mathrm{C}$ (as described in Škaloud et al. 2005). Cultures were regularly checked at half-hour intervals, but despite all efforts, zoospores could not be detected.

\section{Electron and confocal microscopy}

For transmission electron microscopy (TEM), the algal strains were cultivated in liquid BBM under the same regime as described previously. We prepared a mixed sample of each strain from cultures of different ages ( 5 days, 10 days, 2 months). Samples were fixed for 2 hours at $5^{\circ} \mathrm{C}$ in $2 \%$ solution of glutaraldehyde in $0.05 \mathrm{M}$ phosphate buffer and postfixed for 2 hours at $5^{\circ} \mathrm{C}$ in $1 \%$ osmium tetroxide in $0.05 \mathrm{M}$ phosphate buffer and overnight at $5^{\circ} \mathrm{C}$ in $1 \%$ uranyl acetate in methanol. After dehydration through an ethanol series, the strains were embedded in Spurr medium via propylenoxide. Ultrathin sections, cut with a glass knife on a LKB Ultratome, were poststained with uranyl acetate and bismuth oxynitrate and examined with a Philips CM 100 TEM at $80 \mathrm{kV}$.

For investigation of chloroplast morphology and for visualization of nuclei, cells were observed under a Leica TCS SP2 laser scanning confocal microscope. The microscope was equipped with an argon-krypton laser using a 488-nm excitation line and AOBS filter-free system collecting emitted light between 498 and $700 \mathrm{~nm}$. A Leica $63 \times / 1.4$ N.A. oil immersion or $63 \times / 1.2$ water immersion objective fitted on a Leica DM IRE2 inverted microscope was used. A series of optical sections of chloroplasts were captured and used for 3D reconstruction of their morphology. The autofluorescence of the chlorophyll was exploited for visualisation of chloroplast structure. For visualisation of nuclei by DNA staining, DAPI dye $\left(0.5 \mu \mathrm{g} \mathrm{ml}^{-1}\right.$, SigmaAldrich) was added to cells treated with a $0.1 \mathrm{M}$ PBS buffer, following the procedure of Zachleder \& Cepák (1987). For the final processing of confocal images, Leica Confocal Software, version 2.61 (Leica Microsystems), and the Image J 1.34p program (Abramoff et al. 2004) were used.

\section{DNA extraction, PCR and sequencing}

For amplification of the 18S rDNA gene, cells were scraped from agar plates with a clean spatula, transferred to an Eppendorf tube, resuspended in distilled water and harvested by centrifugation. Cells were disrupted using a Retsch mixer mill MM 200 (shaking the cells with glass balls with a diameter of $0.5 \mathrm{~mm}$ for 5 minutes). Total DNA was extracted using the Invisorb ${ }^{\circledR}$ Spin Plant Mini Kit (Invitek). A segment of the 18S rDNA gene [1752 base pairs (bp) excluding primer regions, corresponding to positions 22-1760 of the 18S rRNA gene sequence of Volvox carteri $\mathrm{f}$. nagariensis, EMBL accession number X53904.1] from the UTEX 1707, UTEX 836 and ACKU 177-03 strains was amplified by PCR using universal forward (F) and reverse (R) primers according to Katana et al. (2001). A portion of the 18S rDNA gene from the CAUP H 7802 strain (1700 bp excluding primer regions, corresponding to positions 551742 of the $V$. carteri sequence) was amplified using the $34 \mathrm{~F}$ (T. Friedl, personal communication) and $18 \mathrm{~L}$ primers (Hamby et al. 1988). Two overlapping fragments were amplified from the CAUP H 7801 strain using the 34F forward primer in combination with the green algal-specific reverse primer vivi1650R (T. Friedl, personal communication) and the green algal-specific forward primer $1500 \mathrm{bf}$ (Helms et al. 2001) in combination with the reverse primer ITS4 (White et al. 1990). The assembled sequence (2135 bp) comprised a part of the $18 \mathrm{~S}$ rRNA gene itself $(1741 \mathrm{bp}$ corresponding to positions $55-1765$ of the $V$. carteri sequence) and a $5^{\prime}$ part of an intron region (394 bp). The PCR products were either purified directly using JETQUICK PCR Product Purification Spin Kit (Genomed) or first resolved by electrophoresis on vertical agarose gels, and then bands of expected size were excised DNA extracted using the QIAquick Gel Extraction Kit (Qiagen). The purified DNA fragments from the strains CAUP $\mathrm{H}$ 7802, UTEX 1707, UTEX 836 and ACKU 177-03 and the 34F+vivi1650R fragment from CAUP H 7801 were sequenced from both ends using primers designed according to Katana et al. (2001); whereas, the 1500bf+ITS4 fragment from the same strain was sequenced only at its $5^{\prime}$ end with the $1500 \mathrm{bf}$ primer to obtain a sequence of the $3^{\prime}$ end of the $18 \mathrm{~S}$ rRNA gene. Sequencing reads were assembled with the CAP3 assembler server (http://pbil. univ-lyon1.fr/cap3.php) and manually edited by visual inspection of sequencing chromatograms. The newly 
obtained sequences, excluding the primer regions, were deposited at GenBank with accession numbers EU105208EU105209 and EU878372-EU878374.

\section{Phylogenetic analyses}

BLAST searches and preliminary maximum likelihood (ML) analyses with the newly determined sequences indicated that the corresponding strains are all nested within the Trebouxiophyceae. The sequences were, therefore, added to a comprehensive alignment of trebouxiophycean 18S rDNA sequences ( $>200$ taxa) from the DDBJ/EMBL/GenBank database built using ClustalX (Thompson et al. 1997) and manual editing with GeneDoc (K.B. Nicholas \& H.B. Nicholas, http://www.psc.edu/ biomed/genedoc) guided by the secondary structure model of the Chlamydomonas reinhardtii 18S rRNA available from the European Ribosomal RNA Database (http://www. psb.ugent.be/rRNA/secmodel/Crei_SSU.html; Wuyts et al. 2000). From a distance phylogenetic analysis (using the BioNJ algorithm; Gascuel 1997) of that large sequence alignment, a set of trebouxiophycean sequences representing all major lineages plus sequences from representatives of Chlorophyceae, Ulvophyceae and Chlorodendrales ('Prasinophyceae') were selected for final examination (63 taxa, 1746 positions). The sequence alignment is available from the authors upon request. ML analyses were performed with RAxML 7.0.3 (Stamatakis 2006) using the GTR $+\Gamma+\mathrm{I}$ substitution model. This model was chosen because it is very general and includes other possible models commonly used in the ML framework (e.g. TN93) as its special cases. The ML bootstrapping (100 replicates) was performed with RAxML using the GTR $+\Gamma+\mathrm{I}$ model and the thorough standard bootstrap (-f i option). A Bayesian inference was performed using MrBayes 3.1 (Huelsenbeck \& Ronquist 2001). Two parallel MCMC runs were carried out for 2 million generations each with one cold and three heated chains employing the GTR $+\Gamma+\mathrm{I}$ evolutionary model (with parameters estimated from the data). Trees were sampled every 100 generations. The initial 500 trees of each run were discarded as 'burn-in', and posterior probabilities of tree bipartitions were calculated on the basis of the consensus of the remaining 39,002 trees. A maximum parsimony (MP) analysis was carried out using the DNAPARS program from the PHYLIP v3.6 package (Felsenstein 2004). The MP tree on the original data set was inferred using randomised input order of sequences with 10 times to jumble. MP bootstrapping (on 100 replicates created with the use of SEQBOOT) was run with three times to jumble. The consensus tree for obtaining bootstrap values of branch support was inferred with CONSENSE.

\section{RESULTS}

\section{Xylochloris Neustupa, Eliáš \& Škaloud gen. nov.}

DESCRIPTION: Cellulae vegetativae solitariae, sphaericae vel irregulares, uninucleatae. Paries cellulae laevis. Chloroplastus parietalis, pyrenoide late granis amyli tecto. Propagatio per 4-16 autosporas globulares. Reproductio sexualis non observata. A generibus ceteris familiae ordine nucleotidorum in $18 S \mathrm{rRNA}$ differt.

DESCRIPTION: Vegetative cells solitary and uninucleate. They have a globular or irregular outline and a thin cell wall. Chloroplast is parietal, with a pyrenoid surrounded by numerous starch grains. Reproduction takes place by means of 4-16 globular autospores. Sexual reproduction was not observed. The genus differs from other members of Trebouxiophyceae by the $18 \mathrm{~S}$ rRNA sequence.

The generic name indicates that it was first reported from surface of wood (epixylic habitat).

TYPE SPECIES OF THE GENUS: Xylochloris irregularis.

\section{Xylochloris irregularis Neustupa, Eliáš \& Škaloud sp. nov.}

$$
\text { Figs 1-15 }
$$

DESCRIPTION: Cellulae vegetativae solitariae, sphaericae, pyriformes vel irregulares, uninucleatae, membranis laevibus, (11.0-) 13.5-20.5 (-21.5) × (15.0-) 16.2-25 (-27.5) $\mu \mathrm{m}$ diametro. Chloroplastus parietalis, singulus, lobatus, pyrenoide late granis amyli tecto. Propagatio per 4-16 autosporis globularae, 4-6 um diametro. Reproductio sexualis non observata.

DESCRIPTION: Vegetative cells solitary and uninuclear, with a globular, pyriform or irregular outline and a thin cell wall. The dimensions of vegetative cells are (11.0-) 13.5-20.5 $(-21.5) \times(15.0-)$ 16.2-25 (-27.5) $\mu \mathrm{m}$. Parietal chloroplast with lobed margins and detached from plasmatic membrane at the side closest to the cell wall. A conspicuous pyrenoid surrounded by numerous starch grains. Reproduction by means of 4-16 globular autospores 4-6 $\mu \mathrm{m}$ in diameter. Sexual reproduction was not observed.

HABITAT: Subaerophytic on bark and wood of tropical trees.

TYPE LOCALITY: Central Catchment Nature Reserve, Singapore, latitude $1^{\circ} 21^{\prime} 27^{\prime \prime} \mathrm{N}$, longitude $103^{\circ} 48^{\prime} 32^{\prime \prime} \mathrm{E}$, altitude $50 \mathrm{~m}$ a.s.1.

HOLOTYPE: Cryopreserved material has been deposited in the Culture Collection of Algae of the Charles University of Prague, Czech Republic (CAUP) as specimen No. CRYOH7801.

REFERENCE STRAIN: The living culture (ex-holotype) has been deposited as CAUP H 7801 in the Culture Collection of Algae of the Charles University of Prague, Czech Republic (http://botany.natur.cuni.cz/algo/caup.html).

ETYMOLOGY: The specific epitheton reflects the irregular or pleomorphic cell shape.

\section{Light and electron microscopy}

The strains CAUP H 7801 and CAUP H 7802, described here as members of the new genus and species Xylochloris irregularis, shared identical morphological characteristics at the light-microscopical level. They formed individual coccoid cells with globular to irregularly elliptical outline. Young cells were mostly spherical, possessing a simple 

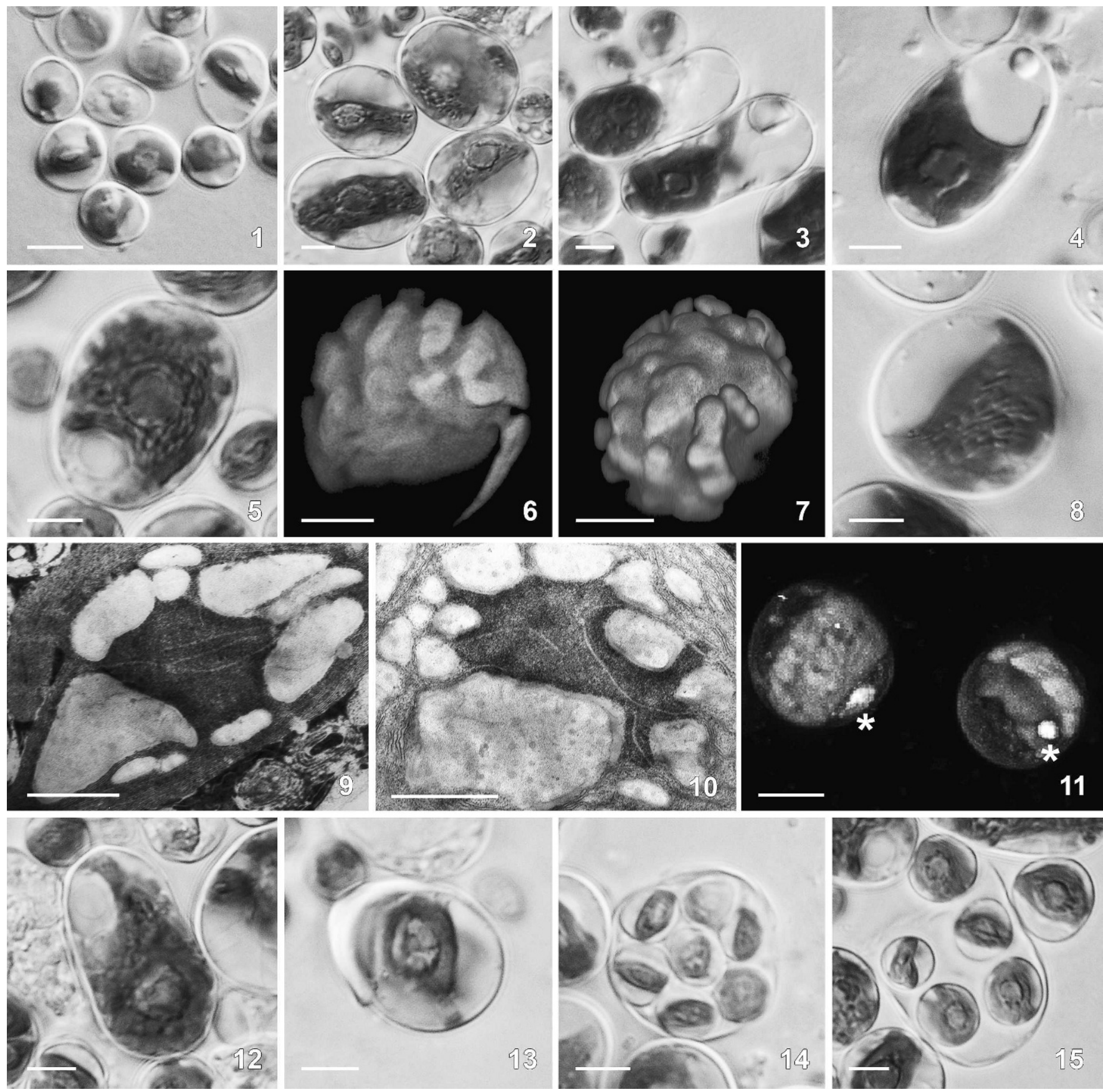

Figs 1-15. Morphology and ultrastructure of Xylochloris irregularis. Scale bars represent: Figs 1-8, 11-15: $5 \mu \mathrm{m}$; Figs 9, 10: $1 \mu \mathrm{m}$.

Fig. 1. Young cells with band-shaped chloroplasts (strain CAUP H 7801).

Fig. 2. Mature cells of spherical and oval shape possessing band-shaped chloroplasts with distinct pyrenoids (CAUP H 7801).

Fig. 3. Cylindrical cells produced in old cultures (CAUP H 7802).

Fig. 4. The mature cell with parietal chloroplast containing a distinct pyrenoid (CAUP H 7801).

Fig. 5. The chloroplast with undulated margins (CAUP H 7801).

Figs 6, 7. Confocal reconstructions of the chloroplast structure. Note the distinctively undulated chloroplast margin (CAUP H 7801).

Fig. 8. The mature cell focused on the pyrenoid surface. Note numerous elliptical starch grains (CAUP H 7802).

Fig. 9. TEM section of pyrenoid (CAUP H 7801).

Fig. 10. TEM section through the entire cell. Note thylakoids penetrating the matrix (CAUP H 7801).

Fig. 11. An overlay of two confocal maximum projection images, showing DAPI-stained nuclei compared with the position of chloroplasts (CAUP H7801). Note the single nucleus per cell (indicated by asterisks).

Fig. 12. A cell with the nucleus in marginal position (CAUP H 7801).

Fig. 13. A local thickening of the cell wall (CAUP H 7801).

Fig. 14. An autosporangium (CAUP H 7801).

Fig. 15. A release of autospores by rupture of mother cell wall (CAUP H 7801). 

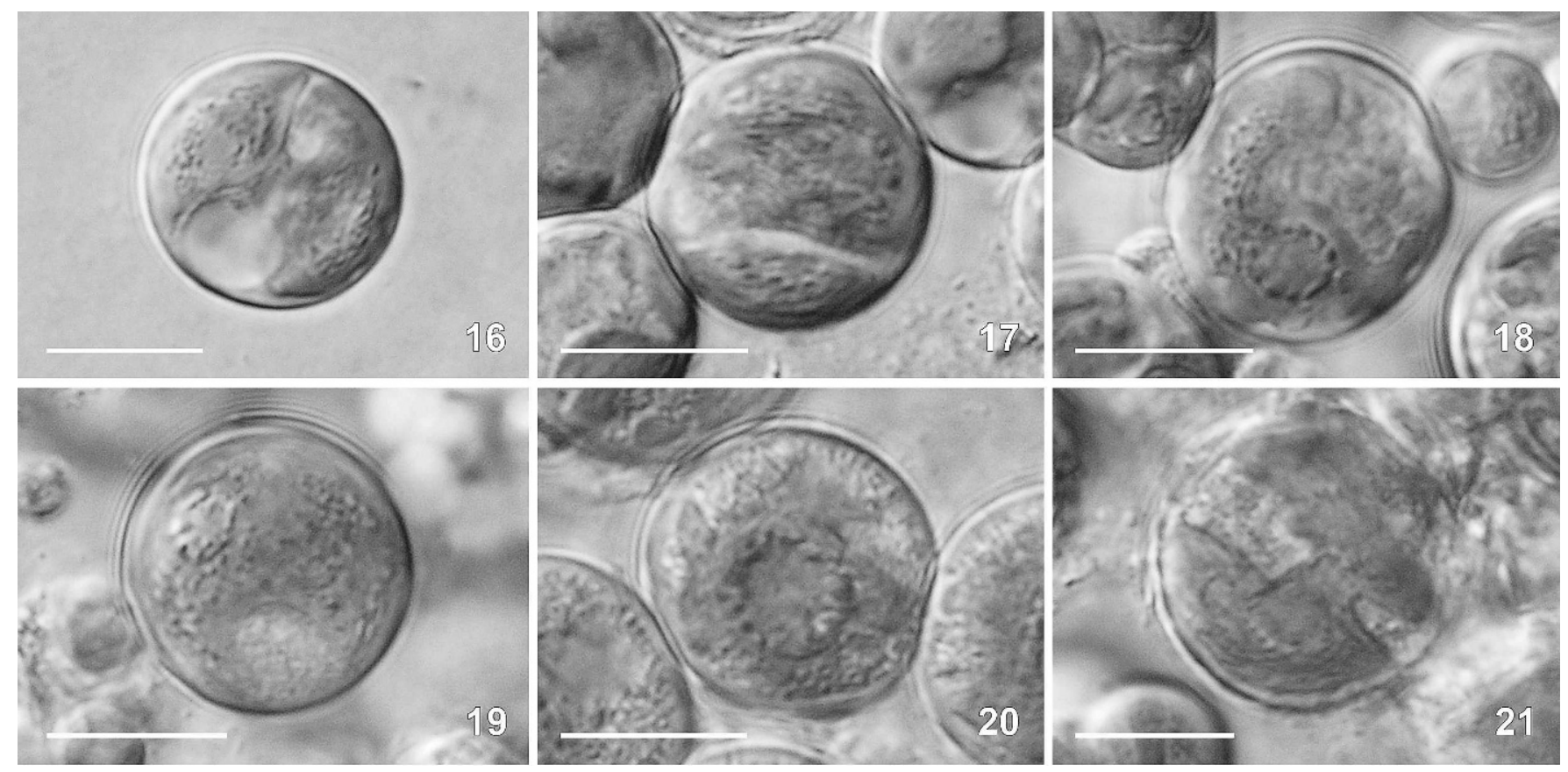

Figs 16-21. Vegetative cells morphology of Parietochloris strains. Scale bar represent $10 \mu \mathrm{m}$.

Figs 16, 17. Parietochloris alveolaris (UTEX 836).

Figs 18, 19. Parietochloris cohaerens (UTEX 1707).

Figs 20, 21. Parietochloris ovoidea (ACKU 177-03).

parietal or band-shaped chloroplast (Fig. 1). Mature cells were globular, elliptical to pyriform (Fig. 2). Dimensions of vegetative cells were (11.0-) 13.5-20.5 (-21.5) $\times(15.0-)$ $16.2-25(-27.5) \mu \mathrm{m}$. In old cultures, highly irregular cells of cylindrical shape were also observed (Fig. 3). Each cell contained a single chloroplast with a prominent pyrenoid (Figs 2-4). The chloroplast was in a parietal position, but in most cells it was slightly detached from the cytoplasmic membrane at its parietal side. Thus, in a side view the chloroplast appeared as a flat plate with a centrally located pyrenoid (Fig. 2). Typically, chloroplasts had lobed margins, similar to the plastid margins of Trebouxia or Asterochloris (Figs 5-7). The pyrenoid was surrounded by small elliptical starch grains (Figs 8, 9). Viewed with TEM, the pyrenoid matrix was irregularly dissected by several thylakoid membranes (Figs 9, 10). The cells were uninuclear and the nucleus was eccentrically located between chloroplast lobes or near the cell margin (Figs 11, 12). The cell wall was generally thin, but in mature cells occasional local thickenings were observed (Fig. 13). Autospores were produced in sporangia containing 4-16 (-32) daughter cells. They were mostly of globular shape, 4-6 $\mu \mathrm{m}$ in diameter (Figs 14, 15). Neither zoospores nor sexual reproduction were observed.

We did not specifically concentrate on a morphological study of the three Parietochloris strains obtained from the culture collections, as these have been investigated and described in detail elsewhere (Bold 1958; Watanabe \& Floyd 1989; Mikhailyuk et al. 2003). However, we checked the morphology of vegetative cells in order to ascertain that they corresponded to their respective taxonomic descriptions. The UTEX 836 strain of $P$. alveolaris had globular vegetative cells with a single parietal chloroplast containing a starch envelope-bearing pyrenoid (Figs 16, 17). The dimensions of vegetative cells were (4.5-) 8.0-21.5 (-26.5) $\mu \mathrm{m}$. The chloroplast was more or less cup-shaped or irregular in young cells but became increasingly lobed in mature vegetative cells (Fig. 17). The cells of the UTEX 1707 strain of $P$. cohaerens had globular vegetative cells with dimensions of (4.0-) 6.0-15.5 (-21.5) $\mu \mathrm{m}$, with a single parietal chloroplast with two to multiple lobes and a prominent pyrenoid surrounded by a starch envelope formed by numerous densely arranged starch grains (Figs 18, 19). The ACKU 177-03 strain of P. ovoidea had generally globular cells with a single parietal, richly lobed chloroplast bearing a prominent pyrenoid surrounded by a starch envelope formed by numerous small starch grains (Fig. 20). The multiple lobes of the chloroplast were somewhat reminiscent of the chloroplast structure of Trebouxia or Asterochloris. On the other hand, two-lobed chloroplasts, similar to those described in Myrmecia species, were present in some cells (Fig. 21). The dimensions of vegetative cells were (4.0-) 6.0-15.5 (-21.5) $\mu \mathrm{m}$.

\section{Molecular phylogeny}

The sequenced segments of the18S rRNA genes of the CAUP H 7801 and CAUP H 7802 strains (2135 and $1700 \mathrm{bp}$, respectively, excluding the regions corresponding to PCR primers) differed by only a single nucleotide in the overlapping region of 1700 nucleotides. The sequence of strain CAUP H 7801 extends at its $3^{\prime}$ end into a putative S1512 group I intron, which is common in trebouxiophycean algae (Bhattacharya et al. 1996; Friedl et al. 2000). 
Whether there is a $\mathrm{S} 1512$ intron in the $18 \mathrm{~S}$ rRNA gene of strain CAUP H 7802 as well remains unknown because the respective intron position lies outside of the portion of the gene that has been amplified. In BLAST searches against the $n r$ database at NCBI (http://www.ncbi.nlm.nih.gov/ BLAST), the CAUP H 7801 and CAUP H 7802 sequences were most similar to sequences from the Trebouxiophyceae, with the highest identity of $95 \%$ only. Phylogenetic analyses including a representative set of sequences from all major lineages of the Chlorophyta confirmed that strains CAUP H 7801 and CAUP H 7802 formed a clade nested within the Trebouxiophyceae (tree not shown). The 18S rDNA sequence from $P$. alveolaris UTEX 836 was most similar to a sequence from Parietochloris pseudalveolaris (Deason \& Bold) Watanabe \& Floyd (M63002.1) with 98\% identity in the BLAST alignment. The $18 \mathrm{~S}$ rDNA sequences from $P$. ovoidea ACKU 177-03 and $P$. cohaerens UTEX 1707 differed from each other at only 2 out of 1752 positions, and both were most similar to sequences from Lobosphaera incisa (Reisigl) Karsten et al., strain SAG 2007 (AY762602) and Lobosphaera tirolensis Reisigl, strain ASIB S234 (AB006051), differing from them at one to three positions. A sequence from Myrmecia bisecta Reisigl, strain IB T74 (Z47209), was slightly more distant with 13 and 11 sequence differences, respectively. Published 18S rDNA phylogenies (e.g. Henley et al. 2004; Karsten et al. 2005) placed these taxa into Trebouxiophyceae, suggesting that $P$. alveolaris, $P$. ovoidea and $P$. cohaerens are members of this class as well.

In order to determine more precisely the phylogenetic position of the newly sequenced strains within the Trebouxiophyceae, we conducted phylogenetic analyses of a data set of $18 \mathrm{~S}$ rDNA sequences covering the breadth of the trebouxiophycean phylogenetic diversity. The resulting ML tree obtained from this data set is shown in Fig. 22. A tree obtained with Bayesian inference exhibited virtually identical topology as the ML tree (not shown). We also performed an MP analysis, which yielded a tree largely congruent with the ML and Bayesian trees and differed only in statistically unsupported bipartitions (not shown). The orders Trebouxiales and Chlorellales sensu lato (including Oocystaceae) were both recovered, albeit neither gained consistent statistical support. We also obtained moderately to strongly supported lineages corresponding to the Prasiola, Choricystis/Botryococcus and Watanabea clades as defined by Karsten et al. (2005). The sequences of the CAUP H 7801 and CAUP H 7802 strains clustered together with $100 \%$ bootstrap support in both ML and MP analyses (MLBS and MPBS) and 1.00 Bayesian posterior probability (BPP; Fig. 22). The CAUP H 7801/7802 lineage was placed in a sister position to Trebouxiales in the ML and Bayesian analyses and in a sister position to the Watanabea clade in the MP analysis, but neither topology was statistically supported. Both $P$. alveolaris and P. pseudalveolaris formed a strongly supported clade $(99 \% /$ 100\%/1.00 MLBS/MPBS/BPP), which was sister to a lineage comprising Microthamnion kuetzingianum and Coleochlamys perforata (Microthamniales; Fig. 22). However, this relationship was supported by the Bayesian analysis only. A tight cluster formed by $P$. ovoidea and $P$. cohaerens together with Lobosphaera incisa and $L$. tirolensis was sister to $M$. bisecta, with $100 \% / 1.00 \mathrm{ML}$ BS/BPP. However, the position of this clade within the Trebouxiophyceae was unresolved in our analyses (Fig. 22).

\section{DISCUSSION}

According to our light- and electron-microscopic observations, the strains CAUP H 7801 and CAUP H 7802, described here as Xylochloris irregularis gen. et sp. nov., did not appear to be attributable to any of the currently known species of coccoid green algae (Komárek \& Fott 1983; Ettl \& Gärtner 1995). Nevertheless, their vegetative cells were similar in some respects to those of species of the genera Parietochloris Watanabe \& Floyd and Ettlia Komárek. The parietal chloroplast containing the pyrenoid surrounded by numerous densely packed elliptical starch grains has already been noted as one of the typical characters of both genera (Komárek 1989; Watanabe \& Floyd 1989). Indeed, the pyrenoid structures of the strains CAUP H 7801 and $\mathrm{H}$ 7802 strains were similar to Parietochloris and Ettlia species; that is, the starch envelope typically consisted of numerous densely packed starch grains, and the pyrenoid matrix was transected by several parallel or irregular thylakoid membranes. However, vegetative cells of strains CAUP H 7801 and H 7802 differed from all the described Parietochloris and Ettlia species by having a notably elliptical to irregular shape and their chloroplast being detached from the cytoplasmic membrane (Figs 1, 2). In both Parietochloris and Ettlia, the formation of zoospores was observed along with formation of autospores (Watanabe \& Floyd 1989; Ettl \& Gärtner 1995). In contrast, we did not detect any zoospores in strains CAUP H 7801 and CAUP H 7802, even at conditions known to induce zoospore production in other species (see Material and Methods). The absence of zoospores can never be considered as entirely certain, as zoospores may be formed very rarely or under some still unknown conditions, but our failure to detect zoospores in cultures of CAUP H 7801 and CAUP H 7802 is in contrast to the readiness with which zoospores were induced in cultures of Parietochloris and Ettlia (= Chlorococcopsis) species by Watanabe \& Floyd (1989). The purely autosporic nature of the investigated strains is thus reminiscent of species of the traditional genus Chlorella. Among these, Chlorella luteoviridis Chodat is clearly the species most similar to X. irregularis. Most notably, the detachment of the plastid from the cytoplasmic membrane at its parietal side is a character shared by $C$. luteoviridis and our strains (Komárek \& Fott 1983). However, the irregular cell shape, the larger cell dimensions and the lobed chloroplast margins in mature cells clearly differentiate both $X$. irregularis from $C$. luteoviridis.

Species of the genera Parietochloris and Ettlia have originally been assigned to the genus Neochloris Starr (Komárek 1989; Watanabe \& Floyd 1989; Deason et al. 1991). However, despite their morphological similarity to that of the traditional Neochloris species, ultrastructural and molecular studies revealed that Parietochloris and 


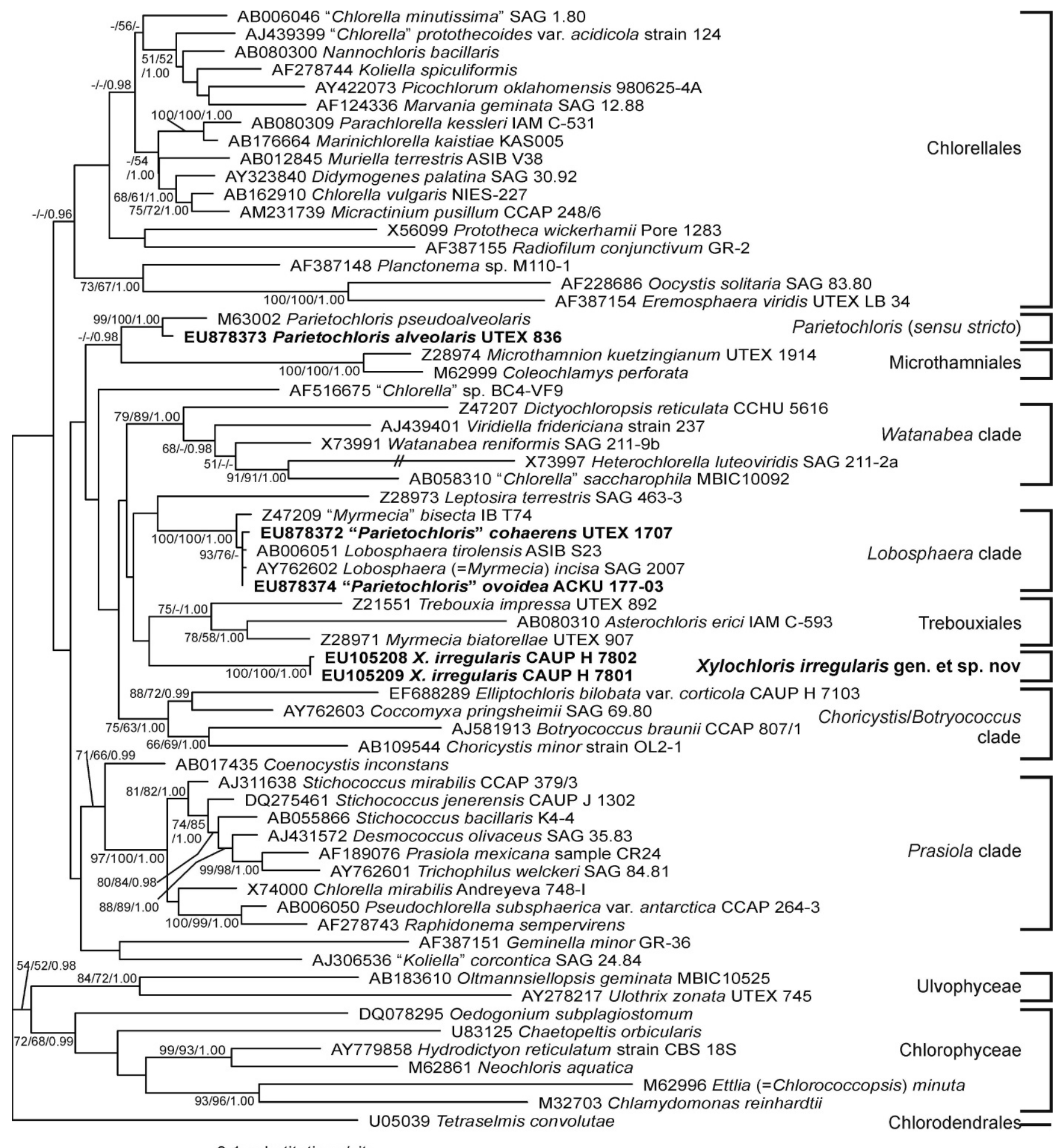

0.1 substitutions/site

Fig. 22. An unrooted ML tree $(\mathrm{GTR}+\Gamma+\mathrm{I}, \log \mathrm{k}=-14676.349116, \alpha=0.523982$, pinv $=0.527688)$ of $18 \mathrm{~S}$ rRNA gene sequences from the Chlorophyta, with a comprehensive representation of the class Trebouxiophyceae (including five new sequences printed in bold) plus representatives of Ulvophyceae, Chlorophyceae and Chlorodendrales ('Prasinophyceae'). Major previously named trebouxiophycean lineages are indicated on the right. ML/MP bootstrap values/Bayesian posterior probabilities are shown for nodes higher than $50 \% / 0.95$. The long branch leading to Heterochlorella luteoviridis has been shortened to its half to fit it into the graphic.

Ettlia species represent several unrelated phylogenetic lineages. Neochloris aquatica Starr, the type species of the genus Neochloris, and related species are characterised by multinucleate cells and directly opposed absolute orienta- tion of flagellar basal bodies in naked zoospores and belong to the order Sphaeropleales in the class Chlorophyceae (Deason et al. 1991; Lewis et al. 1992). Species of the genus Ettlia, including the type species E. carotinosa Komárek 
(= Chlorococcopsis wimmeri Watanabe \& Floyd), have uninucleate cells and clockwise absolute orientation of basal bodies in thin-walled zoospores (Watanabe \& Floyd 1989; Deason et al. 1991), suggesting a relationship with other taxa with clockwise orientation of the basal bodies, such as the order Volvocales (= Chlamydomonadales), in the class Chlorophyceae. A volvocalean affinity of $E$. carotinosa strain SAG 213-4 was found when its sequence (GenBank accession number GU292342) was added to our data set and phylogenetically analysed. The latter sequence had a $99 \%$ identity with several sequences of Haematococcus species (with the sequence FJ877140 from Haematococcus sp. KORDI03 being most similar). Likewise, E. minuta (Arce \& Bold) Komárek (M62996; strain UTEX 776 ) is placed into the Volvocales in the 18S rDNA phylogenies (Lewis et al. 1992; see also Fig. 22). Our preliminary analyses showed, however, that the two species of Ettlia were not closely related to each other (data not shown).

Finally, the genus Parietochloris is characterised by uninucleate cells and naked zoospores with counterclockwise absolute orientation of basal bodies (Watanabe \& Floyd 1989). Based on these features, Watanabe \& Floyd (1989) attributed the genus Parietochloris to the class Pleurastrophyceae (later emended as Trebouxiophyceae; Friedl 1995). The $18 \mathrm{~S}$ rRNA gene sequence determined for $P$. pseudalveolaris confirms this assumption (Lewis et al. 1992), but prior to our present study no sequence data existed for other species, including the type species $P$. alveolaris (Bold) Watanabe \& Floyd.

This history demonstrates that apart from the ultrastructure of the flagellar apparatus, other morphological features of coccoid green algae provide few clues as to their phylogenetic position within the Chlorophyta (e.g. Krienitz et al. 2003). Because both strains of $X$. irregularis, CAUP H 7801 and H 7802, did not form zoospores, we could not define their phylogenetic position within the Chlorophyta, even at the class level, from morphological observations only. Here molecular characters are required, and indeed, our analyses of the $18 \mathrm{~S}$ rDNA sequences clearly showed that $X$. irregularis belongs to the Trebouxiophyceae (Fig. 22). The placement of strains CAUP H 7801 and $H$ 7802 within the Trebouxiophyceae, although difficult to predict from morphological features only, is not unexpected given the existence of a number of exclusively autosporic lineages in this class as revealed by previous studies (e.g. Friedl 1995; Katana et al. 2001; Krienitz et al. 2003; Karsten et al. 2005; Eliáš et al. 2008; Neustupa et al. 2009).

The phylogeny of Trebouxiophyceae presented in this study is congruent with phylogenies previously presented for this green algal class, but statistical support for the deepest internal nodes and even the monophyly of Trebouxiophyceae is lacking (compare to e.g. Krienitz et al. 2004; Henley et al. 2004; Fawley et al. 2005; Karsten et al. 2005; Aslam et al. 2007; Eliáš et al. 2008; Sluiman et al. 2008). As a result, strains CAUP $H 7801$ and CAUP H 7802 do not fit into any statistically supported higher-order branch, so it is currently impossible to determine a sister group for the Xylochloris lineage. This may be due to the inherent limitations of single-gene analyses, and adding extensive data from other genes will be crucial for resolving interrelationships among individual trebouxiophycean lineages, including the Xylochloris lineage. Moreover, specifying the precise position of Xylochloris within Trebouxiophyceae may require adding sequence data from its potential closer relatives, which may also occur somewhere in the tropical or subtropical regions. Nevertheless, according to the $18 \mathrm{~S}$ rRNA gene-based phylogeny, $X$. irregularis is not closely allied with any of the morphologically similar taxa, including $H$. luteoviridis or species of Parietochloris (Fig. 22). Together with the morphological peculiarities of strains CAUP H 7801 and CAUP H 7802, these results indicate that we have identified a new trebouxiophycean lineage independent from all others sampled thus far. Furthermore, that there is not more than a single $18 \mathrm{~S}$ rDNA sequence position difference between both strains supports the morphological observations suggesting that they may represent the same species. We therefore propose that they are best formally described as a single new species of a new genus.

With the three new sequences determined here, the $18 \mathrm{~S}$ rRNA genes have been sequenced for almost all hitherto described species of Parietochloris, except for $P$. bilobata (Vinatzer) Andreyeva (1998), for which no authentic strain is available in culture collections and which Watanabe (1983) treated as probably synonymous to Neochloris $(=$ Parietochloris $)$ alveolaris. Our phylogenetic analyses placed the Parietochloris species into the class Trebouxiophyceae (Fig. 22), in agreement with the prediction by Watanabe \& Floyd (1989) (see above). However, Parietochloris as currently circumscribed is clearly polyphyletic since only $P$. pseudalveolaris is closely related to $P$. alveolaris, the type species of the genus (Watanabe \& Floyd 1989). Therefore, only the latter two species actually represent the genus Parietochloris. In contrast, $P$. cohaerens and $P$. ovoidea form a strongly supported monophyletic lineage distinct from Parietochloris but share a common origin with Lobosphaera (L. tirolensis, L. incisa), and Myrmecia bisecta in the $18 \mathrm{~S}$ rRNA gene phylogenies. It is possible that $P$. cohaerens and $P$. ovoidea will prove to represent species of the genus Lobosphaera, but additional morphological and molecular studies are required to clarify their actual status.

\section{ACKNOWLEDGEMENTS}

We thank the reviewers for constructive comments on the manuscript and T. Friedl for his discussion and editorial corrections. We are indebted to Veronika Kučabová and Eva Dušková for their technical assistance. This work was supported by grant no. 206/06/0998 of the Czech Science Foundation and partly by research project no. 21620828 of Czech Ministry of Education. We thank Dr Jana Leong and Prof. Benito C. Tan from the National Botanical Garden of Singapore for their kind cooperation in arranging permission for sampling (no. NP/RP757) and for their field assistance. 
Neustupa et al.: Xylochloris irregularis gen. et sp. nov.

\section{REFERENCES}

Abramoff, M.D., Magelhaes P.J. \& Ram S.J. 2004. Image processing with ImageJ. Biophotonics International 11: 36-42.

ANDREYeVA V.M. 1998. Terrestrial and aerophilic green algae (Chlorophyta: Tetrasporales, Chlorococcales, Chlorosarcinales). Nauka, St. Petersburg. 351 pp.

Aslam Z., Shin W.G., Kim M.K., Im W.T. \& Lee S.T. 2007. Marinichlorella kaistiae gen. et sp nov (Trebouxiophyceae, Chlorophyta) based on polyphasic taxonomy. Journal of Phycology 43: 576-584.

Bhattacharya D., Friedl T. \& Damberger S. 1996. Nuclearencoded rDNA group I introns: origin and phylogenetic relationships of insertion site lineages in the green algae. Molecular Biology and Evolution 13: 978-989.

Bischoff H.W. \& Bold H.C. 1963. Phycological studies. IV. Some soil algae from Enchanted Rock and related algal species. University of Texas Publications 6318: 1-95.

Bold H.C. 1958. Three new chlorophycean algae. American Journal of Botany 45: 737-743.

Deason T.R., Silva P.C., Watanabe S. \& Floyd G.L. 1991. Taxonomic status of the species of the green algal genus Neochloris. Plant Systematics and Evolution 177: 213-219.

Eliáš M. \& Neustupa J. 2009. Pseudomarvania gen. nov. (Chlorophyta, Trebouxiophyceae), a new genus for the 'budding' subaerial green algae Marvania aerophytica Neustupa \& Šejnohová and Stichococcus ampulliformis Handa. Fottea 9: 169-177.

Eliáš M., Neustupa J. \& ŠKaloud P. 2008. Elliptochloris bilobata var. corticola var. nov. (Trebouxiophyceae, Chlorophyta), a novel subaerial coccal green alga. Biologia 63: 787-794.

Eliáš M., NĚmcová Y., Škaloud P., Neustupa J., Kaufnerová V. \& ŠEJNOHOVÁ L. 2010. Hylodesmus singaporensis gen. et sp. nov., a new autosporine subaerial green alga (Scenedesmaceae, Chlorophyta) from Singapore. International Journal of Systematic and Evolutionary Microbiology 60: 1224-1235.

EtTl H. \& Gärtner G. 1995. Syllabus der Boden-, Luft- und Flechtenalgen. G. Fischer, Stuttgart. 721 pp.

FaWley M.W., Fawley K.P. \& OWen H.A. 2005. Diversity and ecology of small coccoid green algae from Lake Itasca, Minnesota, USA, including Meyerella planktonica, gen. et sp. nov. Phycologia 44: 35-48.

FELSENSTEIN J. 2004. PHYLIP (Phylogeny Inference Package) version 3.6. Distributed by the author. Department of Genome Sciences, University of Washington, Seattle. Available at: http:// evolution.genetics.washington.edu/phylip.html. Accessed June 28, 2010.

FRIEDL T. 1995. Inferring taxonomic positions and testing genus level assignments in coccoid green lichen algae: a phylogenetic analysis of $18 \mathrm{~S}$ ribosomal RNA sequences from Dictyochloropsis reticulata and from members of the genus Myrmecia (Chlorophyta, Trebouxiophyceae, cl. Nov.). Journal of Phycology 31: 632-639.

Friedl T., Besendahl A., Pfeiffer P. \& Bhattacharya D. 2000. The distribution of group I introns in lichen algae suggests that lichenization facilitates intron lateral transfer. Molecular Phylogenetics and Evolution 14: 342-352.

GASCUEL O. 1997. BIONJ: an improved version of the NJ algorithm based on a simple model of sequence data. Molecular Biology and Evolution 14: 685-695.

Hamby R.K., Sims L.E., Issle L.E. \& Zimmer E.A. 1988. Direct RNA sequencing: optimization of extraction and sequencing techniques for work with higher plants. Plant Molecular Biology Reporter 6: 179-197.

Helms G., Friedl T., Rambold G. \& Mayrhofer H. 2001. Identification of photobionts from the lichen family Physciaceae using algal-specific ITS rDNA sequencing. Lichenologist 33: $73-86$.

Henley W.J., Hironaka J.L., Guillou L., Buchheim M.A., Buchieim J.A., Fawley M.W. \& Fawley K.P. 2004. Phylogenetic analysis of the 'Nannochloris-like' algae and diagnoses of Picochlorum oklahomensis gen. et sp. nov. (Trebouxiophyceae, Chlorophyta). Phycologia 43: 641-652.
Huelsenbeck J.P. \& RonQuist F. 2001. MrBayes: Bayesian inference of phylogenetic trees. Bioinformatics 17: 754 755 .

Karsten U., Friedl T. Schumann R. Hoyer K. \& Lembcke S. 2005. Mycosporine-like amino acids and phylogenies in green algae: Prasiola and its relatives from the Trebouxiophyceae (Chlorophyta). Journal of Phycology 41: 557-566.

Katana A., Kwiatowski J., Spalik K., Zakrys B., Szalacha E. \& SZYMANSKA H. 2001. Phylogenetic position of Koliella (Chlorophyta) as inferred from nuclear and chloroplast small subunit rDNA. Journal of Phycology 37: 443-451.

KomÁreK J. 1989. Polynuclearity of vegetative cells in coccal green algae from the family Neochloridaceae. Archiv für Protistenkunde 137: 255-273.

KomÁrek J. \& FotT B. 1983. Chlorococcales. In: Das Phytoplankton des Süßwassers 7 (Ed. by G. Huber-Pestalozzi), pp. 1-1043. Schweizerbart Verlag, Stuttgart.

Kostikov I.J., Demcenko E.N. \& Berezovskaya M.A. 2009. Kollekcija kultur vodoroslej Kievskogo nacionalnogo universiteta imeni Tarasa Shevchenko. Katalog shtammov (2008 g.). Chornomorskij Botanichnij Zhurnal 5: 37-79.

Krienitz L., Hegewald E., Hepperle D. \& Wolf M. 2003. The systematics of coccoid green algae: 18S rRNA gene sequence data versus morphology. Biologia 58: 437-446.

Krienitz L., Hegewald E.H., Hepperle D., Huss V.A.R., Rohrs T. \& Wolf M. 2004. Phylogenetic relationship of Chlorella and Parachlorella gen. nov (Chlorophyta, Trebouxiophyceae). Phycologia 43: 529-542.

Lewis L.A. \& Flechtner V.R. 2004. Cryptic species of Scenedesmus (Chlorophyta) from desert soil communities of Western North America. Journal of Phycology 40: 11271137.

Lewis L.A. \& McCourt R.M. 2004. Green algae and the origin of land plants. American Journal of Botany 91: 15351556.

Lewis L.A., Wilcox L.W., Fuerst P.A. \& Floyd G.L. 1992. Concordance of molecular and ultrastructural data in the study of zoosporic chlorococcalean green algae. Journal of Phycology 28: $375-380$

Mikhailyuk T.I., Demchenko E.M. \& Kondratyuk S.Y. 2003. Parietochloris ovoideus sp. nova (Trebouxiophyceae, Chlorophyta), a new aerophyte alga from Ukraine. Algological Studies 149: $1-16$.

Neustupa J., Eliáš M. \& ŠEjnohová L. 2007. A taxonomic study of two Stichococcus species (Trebouxiophyceae, Chlorophyta) with a starch-enveloped pyrenoid. Nova Hedwigia 84: 51-63.

Neustupa J., Němcová Y., Eliáš M. \& ŠKaloud P. 2009. Kalinella bambusicola gen. et sp. nov. (Trebouxiophyceae, Chlorophyta), a novel coccoid Chlorella-like subaerial alga from Southeast Asia. Phycological Research 57: 159-169.

Rindi F., López-Bautista J.M., Sherwood A.R. \& Guiry M.D. 2006. Morphology and phylogenetic position of Spongiochrysis hawaiiensis gen. et sp. nov., the first known terrestrial member of the order Cladophorales (Ulvophyceae, Chlorophyta). International Journal of Systematic and Evolutionary Microbiology 56: 913-922.

ŠKALOUD P. 2006. Variation and taxonomic significance of some morphological features in European strains of Klebsormidium (Klebsormidiophyceae, Streptophyta). Nova Hedwigia 83: $533-550$.

ŠKaloud P., Neustupa J., Radochová B. \& Kubínová L. 2005. Confocal microscopy of chloroplast morphology and ontogeny in three strains of Dictyochloropsis (Trebouxiophyceae, Chlorophyta). Phycologia 44: 261-269.

Sluiman H.J., Guihal C. \& Mudimu O. 2008. Assessing phylogenetic affinities and species delimitations in Klebsormidiales (Streptophyta): nuclear-encoded rDNA phylogenies and its secondary structure models in Klebsormidium, Hormidiella, and Entransia. Journal of Phycology 44: 183195.

StAmatakis A. 2006. RAxML-VI-HPC: maximum likelihoodbased phylogenetic analyses with thousands of taxa and mixed models. Bioinformatics 22: 2688-2690. 
Thompson J.D., Gibson T.J., Plewniak F., Jeanmougin F. \& HigGins D.G. 1997. The CLUSTAL_X windows interface: flexible strategies for multiple sequence alignment aided by quality analysis tools. Nucleic Acids Research 25: 48764882.

Tschermak-Woess E., Hua M., GÄrtner G. \& Hesse M. 2006. Observations in Hemichloris antarctica Tschermak-Woess \& Friedmann (Chlorophyceae) and the occurrence of a second Hemichloris species, Hemichloris polyspora n. sp. Plant Systematics and Evolution 258: 27-37.

WATANABE S. 1983. New and interesting green algae from soils of some Asian and Oceanic regions. Archiv für Protistenkunde 127: $223-270$.

Watanabe S. \& Floyd G.L. 1989. Comparative ultrastructure of the zoospores of nine species of Neochloris (Chlorophyta). Plant Systematics and Evolution 168: 195219.
Wuyts J., De Rijk P., Vandepeer Y., Pison G., Rousseeun P. \& De WACHTER R. 2000. Comparative analysis of more than 3000 sequences reveals the existence of two pseudoknots in area V4 of eukaryotic small subunit ribosomal RNA. Nucleic Acids Research 28: 4698-4708.

ZACHLEDER V. \& CEPÁK V. 1987. Visualization of DNA containing structures by fluorochrome DAPI in those algal cells which are not freely permeable to the dye. Algological Studies 47: 157-168. Zhang J.M., Huss V.A.R., Sun X.P., Chang K.J. \& Pang D.B. 2008. Morphology and phylogenetic position of a trebouxiophycean green alga (Chlorophyta) growing on the rubber tree, Hevea brasiliensis, with the description of a new genus and species. European Journal of Phycology 43: 185-193.

Received 6 August 2008; accepted 26 May 2010 Associate editor: Thomas Friedl 